\title{
BASAL STUDY ON EARLY DIAGNOSIS OF CADMIUM POISONING: CHANGE IN CARBONIC ANHYDRASE ACTIVITY
}

\author{
Eiichi OGAWA, Shiro SUZUKI, Hiroshi TSUZUKI* \\ and Mutsuko KAWAJIRI* \\ Department of Pharmacology, School of Medicine, Gunma University, Maebashi and \\ * Maebashi Laboratory, Institute of Radioisotopes, Gunma University, \\ Maebashi, Japan
}

Accepted 29. August 1972

\begin{abstract}
Cadmium chloride solution (contained 146 PPM of Cd) was administered to mice as drinking fluid for 90 days. Carbonic anhydrase activity was unaffected in blood, liver and kidneys 10 days after administration, however, enzymic activity was significantly reduced in all three organs thereafter. Catalase activity was unchanged until day 31 , but was significantly reduced in all organs thereafter. Hemoglobin levels remained unchanged after 10 and 20 days administration, but were significantly reduced thereafter.

Time course of response of carbonic anhydrase and catalase activities and blood hemoglobin level to $\mathrm{CdCl}_{2} \cdot 2 \frac{1}{2} \mathrm{H}_{2} \mathrm{O}$ in a dose of $10 \mathrm{mg} / \mathrm{kg}$ were examined at intervals ranging from 4 to $24 \mathrm{hr}$ after a single s.c. injection. Carbonic anhydrase activity in liver, kidney and blood was significantly decreased every time, however, catalase activity in the above organs as well as the blood hemoglobin level did not change at any time.

Whole-body retention of orally administered ${ }^{115 \mathrm{~m}} \mathrm{CdCl}_{2}$ with or without the carrier was examined at one week intervals for 30 days. Whole-body retention of ${ }^{115 \mathrm{~m}} \mathrm{Cd}$ was significantly less in the carrier group than in the carrier-free group. Average Cd uptake for 30 days was $0.56 \mu \mathrm{g} /$ day in the carrier-free group and $0.1 \mathrm{mg} /$ day in the carrier group. Cd concentration in liver and kidneys on day 31 was 0.04 and 0.15 PPM respectively in the carrier-free group and each 24 PPM in the carrier group.
\end{abstract}

Various metabolic disturbances in humans induced by chronic cadmium (Cd) poisoning are increasing with the increased use of $\mathrm{Cd}$ in modern industry. Furthermore, chronic $\mathrm{Cd}$ intoxication is termed "Itai-itai disease" in Japan and establishment of diagnostic and therapeutic methods are urgently required.

Although the diagnosis based on the functional and/or morphological examination of blood, liver, kidney, lung and bones are useful to determine $\mathrm{Cd}$ poisoning, extensive studies on the early diagnosis of this poisoning as well as systematic and reliable methods have not yet been established. Moreover, biochemical indices which are specific and sensitive to $\mathrm{Cd}$ and have a correlation with the concentration of $\mathrm{Cd}$ in blood, urine and feces are still unavailable.

The theme of this paper was reported at the 45th Annual Meeting of Japanese Pharmacological Society in April, 1972. 
Hypochromic anemia (1) and proteinuria (2) in cadmium poisoning are well established, but changes in the enzyme system in serum are still incomplete. Stowe and Gover (3) reported that serum GOT, GPT, alkaline phosphatase and LDH isozyme values were within normal limits in cadmium-poisoned rabbits. Jacobs et al. (4) reported that Cd acts in vitro as an uncoupler on the oxidative phosphorilation in liver mitochondria.

As for the effect of cadmium on carbonic anhydrase, Meldrum and Roughton (5) previously reported negative results on blood enzymic activity in vitro. Whereas, Hodgen et al. (6) recently reported that $\mathrm{CdCl}_{2}$ acts in vivo and in vitro as an inhibitor on carbonic anhydrase of rat testes. Johnson and Walker (7) also reported similar results, however, the effect of $\mathrm{Cd}$ on carbonic anhydrase activity in organs other than the testis has not been observed. Our in vivo experiments demonstrated that carbonic anhydrase activity was inhibited in blood, liver and kidney after $\mathrm{CdCl}_{2}$ treatment. Experimental data are outlined below.

\section{MATERIALS AND METHODS}

Adult male ddN strain mice weighing approx. $30 \mathrm{~g}$ were used. The aninals were fed a commercial solid diet (Oriental Co.) and tap water ad lib. until the start of the experiment. Experiments completed, the animals were sacrificed by decapitation, liver and kidneys were removed and homogenized in a Potter-Elvehjem type glass-teflon homogenizer with $0.25 \mathrm{M}$ sucrose adjusted to $\mathrm{pH} 7.4$ with $1 \mathrm{M}$ Tris buffer solution. The tissue homogenates were centrifuged in a refrigerated centrifuge at $0^{\circ} \mathrm{C}$ for $20 \mathrm{~min}(9,000 \times g)$ to sediment the nuclei, mitochondria and red blood cells. The supernatant was decanted and used as enzyme sample. In the case of blood, 100-fold and 400-fold diluted blood with distilled water was used for the assay of carbonic anhydrase and catalase activities, respectively. Carbonic anhydrase activity was manometrically assayed by the method of Altschule and Levis (8) and catalase activity was examined by our manometric method (9). Protein content of enzyme sample was determined by Biuret reaction (10) with crystalline bovine serum albumin (Sigma Chem. Co.) used as protein standard. Both enzymic activities were expressed per milligram protein. Hemoglobin concentration in blood was measured by spectrophotometric method (11). In some cases, blood hemoglobin contained in liver and kidney supernatant which was obtained from 105,000 $\times g$ centrifugation for $90 \mathrm{~min}$ was measured by the same method.

In the tracer experiment, ${ }^{115 \mathrm{~m}} \mathrm{CdCl}_{2}$ was used. Whole-body radioactivity was determined with a whole-body animal counter and radioactivity in liver and kidney was measured using a G-M counter.

\section{RESULTS}

Effect of oral administration of cadmium chloride on the activities of carbonic anhydrase and catalase and hemoglobin level

Tap water containing 146 PPM of Cd was given ad lib. to 5 experimental groups of 5 mice for 10, 20, 30, 60 and 90 days, respectively. Five control groups were given tap 
TABLE 1. Effect of oral $\mathrm{CdCl}_{2}$ on carbonic anhydrase activity.

\begin{tabular}{lccccc}
\hline \multirow{2}{*}{ Group } & \multirow{2}{*}{$\begin{array}{c}\text { Time } \\
\text { (days) }\end{array}$} & $\begin{array}{c}\text { No. of } \\
\text { mice }\end{array}$ & \multicolumn{3}{c}{ Carbonic anhydrase activity } \\
\cline { 4 - 6 } & & & Blood $^{1)}$ & Kidney $^{2)}$ & Liver $^{3)}$ \\
\hline Control & & 25 & $(1.02 \pm 0.03)$ & $(1.05 \pm 0.04)$ & $(0.54 \pm 0.05)$ \\
& & & 100 & 100 & 100 \\
Cd-treated & 10 & 5 & 97 & 98 & 95 \\
& 20 & 5 & $76^{*}$ & $74^{*}$ & $74^{*}$ \\
& 30 & 5 & $70^{*}$ & $68^{*}$ & $73^{*}$ \\
& 60 & 5 & $69^{*}$ & $66^{*}$ & $63^{*}$ \\
& 90 & 5 & 68 & $64^{*}$ & $63^{*}$ \\
\hline
\end{tabular}

1) $: \mathrm{EU} / 0.5 \mathrm{ml}, 1: 100 \mathrm{blood}, 2): \mathrm{EU} / \mathrm{mg}$ protein

$*: \mathrm{P}<0.05$,

Control values (Mean \pm S.D.) were expressed as 100 .

TABLE 2. Effects of oral $\mathrm{CdCl}_{2}$ on catalase activity and $\mathrm{Hb}$.

\begin{tabular}{|c|c|c|c|c|c|c|}
\hline \multirow{2}{*}{ Group } & \multirow{2}{*}{$\begin{array}{l}\text { Time } \\
\text { (days) }\end{array}$} & \multirow{2}{*}{$\begin{array}{l}\text { No. of } \\
\text { mice }\end{array}$} & \multicolumn{3}{|c|}{ Catalase activity } & \multirow{2}{*}{ Blood $^{3)} \mathrm{Hb}$} \\
\hline & & & Blood $^{1)}$ & Kidney ${ }^{2)}$ & Liver $^{2)}$ & \\
\hline \multirow{2}{*}{ Control } & & 30 & $(1.44 \pm 0.04)$ & $(30.2 \pm 0.5)$ & $(58.5 \pm 1.3)$ & $(2.11 \pm 0.17)$ \\
\hline & & & 100 & 100 & 100 & 100 \\
\hline \multirow[t]{5}{*}{ Cd-treated } & 10 & 5 & 98 & 102 & 99 & 91 \\
\hline & 20 & 5 & 89 & 100 & 100 & 92 \\
\hline & 30 & 5 & 89 & 100 & 100 & $80 *$ \\
\hline & 60 & 5 & $88 *$ & $86^{*}$ & $86^{*}$ & $61^{*}$ \\
\hline & 90 & 5 & $86^{*}$ & $83^{*}$ & $84^{*}$ & $52 *$ \\
\hline
\end{tabular}

1) : EU/0.5 ml of 400 fold-diluted blood, 2) $: \mathrm{EU} / \mathrm{mg}$ protein 3$): \mathrm{mM}, *: \mathrm{P}<0.05$

Control values (Mean \pm S.D.) were expressed as 100 .

water without $\mathrm{Cd}$. As shown in Table 1, carbonic anhydrase activities in liver, kidney and blood remained unchanged after 10 days administration, whereas significant decreases were observed in all the three organs thereafter. Catalase activity in liver, kidney and blood was not affected after 10, 20 and 30 days administration, however, the enzymic activity decreased significantly after 60 and 90 days administration (Table 2). The degree of inhibition in catalase activity was less than that in carbonic anhydrase activity. Blood hemoglobin level was unaffected until 20th day with a significant decrease thereafter (Table 2).

Effect of subcutaneous injection of cadmium chloride on the activities of carbonic anhydrase and catalase and hemoglobin level

Fig. 1 shows the changes of carbonic anhydrase activity in liver, kidney and blood at $4,8,16$ and $24 \mathrm{hr}$ after s.c. injection of $\mathrm{CdCl}_{2} \cdot 2{ }^{1} /{ }_{2} \mathrm{H}_{2} \mathrm{O}$ in a dose of $10 \mathrm{mg} / \mathrm{kg}$. Carbonic anhydrase activity gradually decreased after a single injection of $\mathrm{Cd}$ and the maximal decrease was observed at $8 \mathrm{hr}$ in the kidney and $16 \mathrm{hr}$ in the liver and blood. Catalase activity and blood hemoglobin concentration in the three organs showed no sig- 


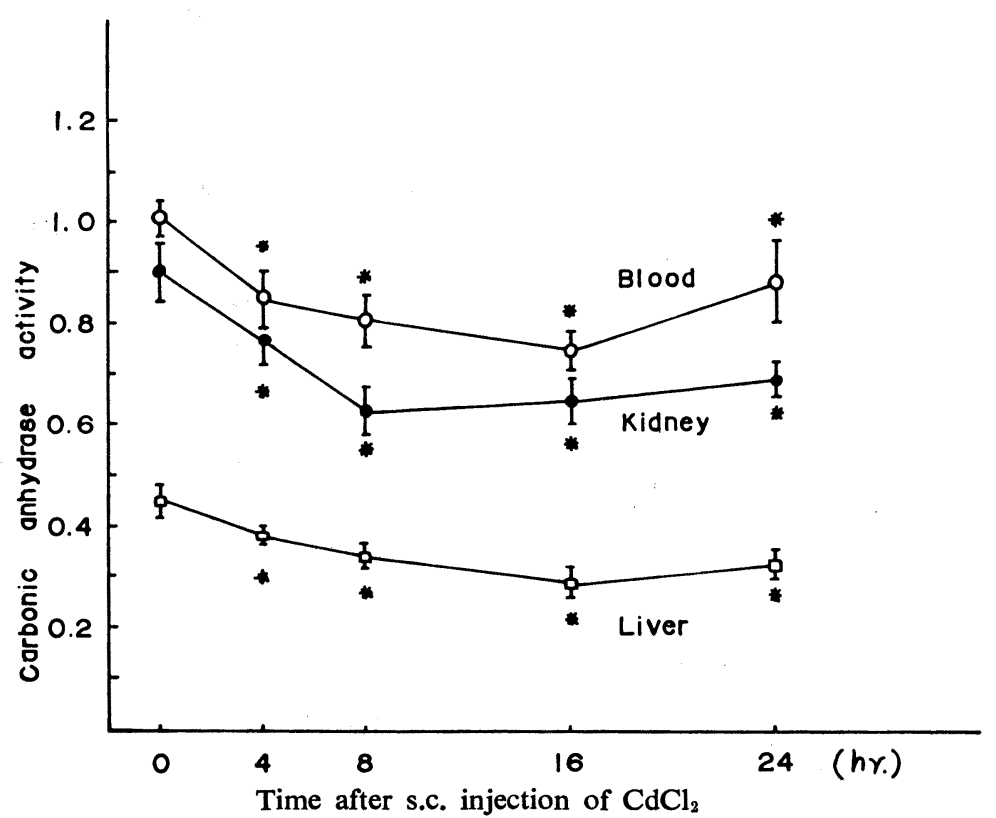

Fig. 1. Effect of s.c. injection of cadmium chloride on carbonic anhydrase activity.

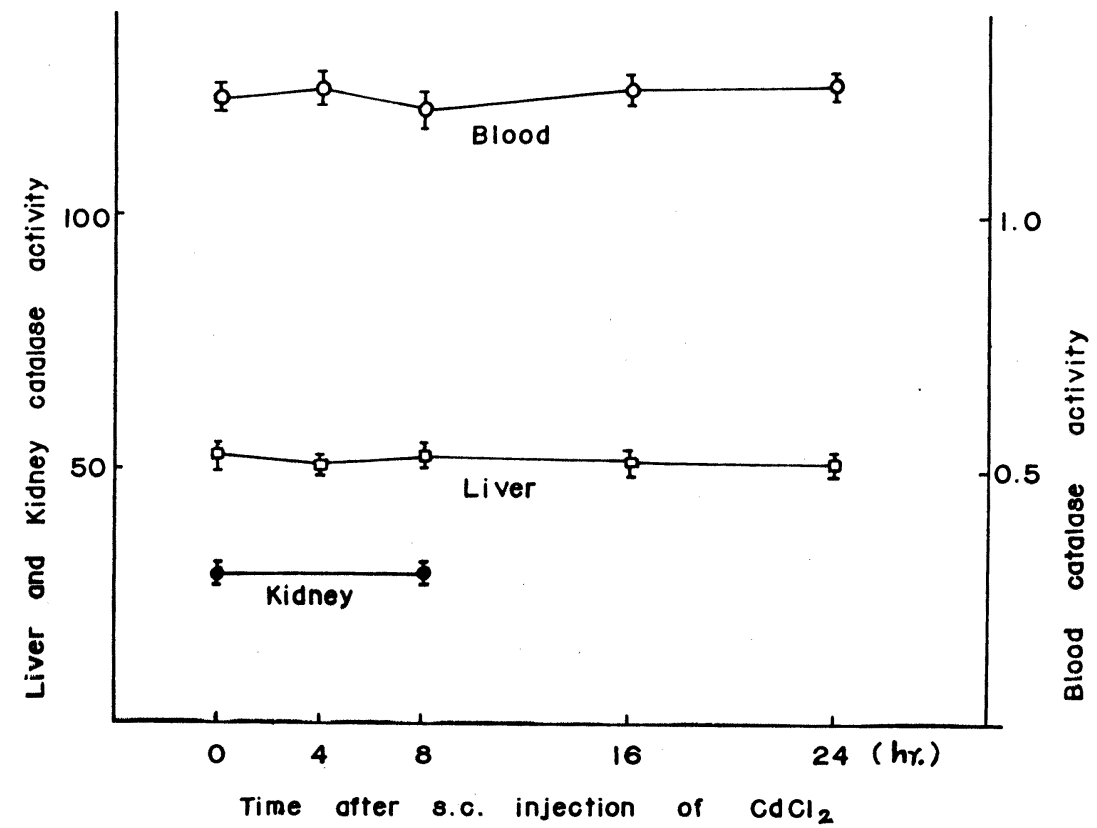

FIG. 2. Effect of s.c. injection of cadmium chloride on catalase activity.

nificant changes at any time (Figs. 2 and 3).

As carbonic anhydrase activity is highest in blood, it appears necessary to ascertain the contamination of liver and kidney samples by blood as well as the influence on the 


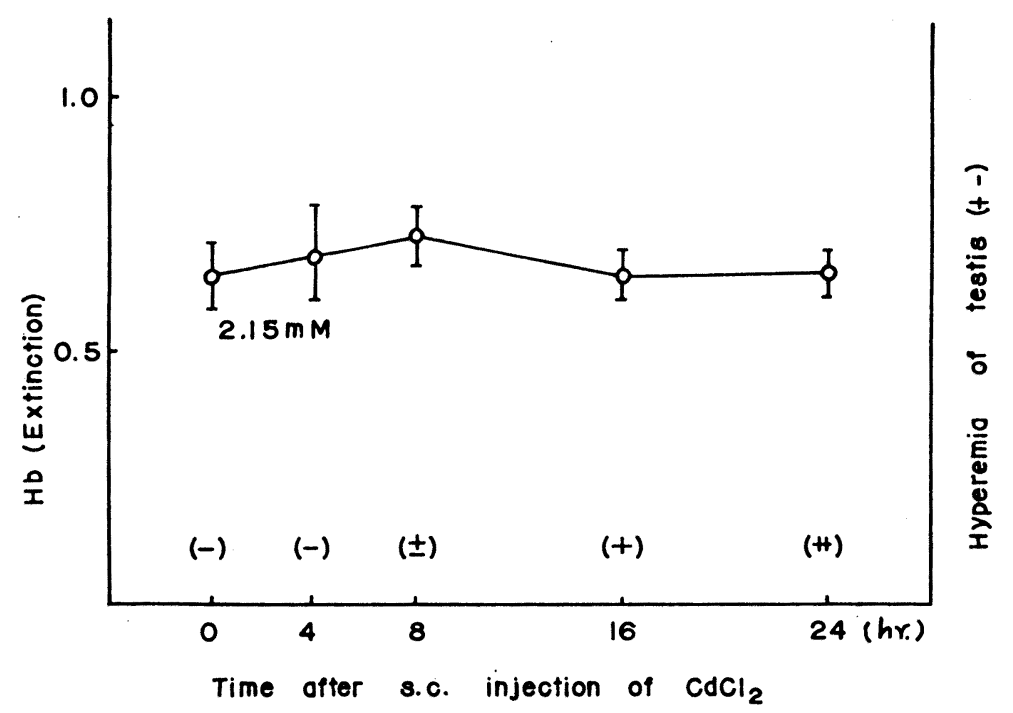

Fig. 3. Effect of s.c. injection of cadmium chloride on hemoglobin concentration.

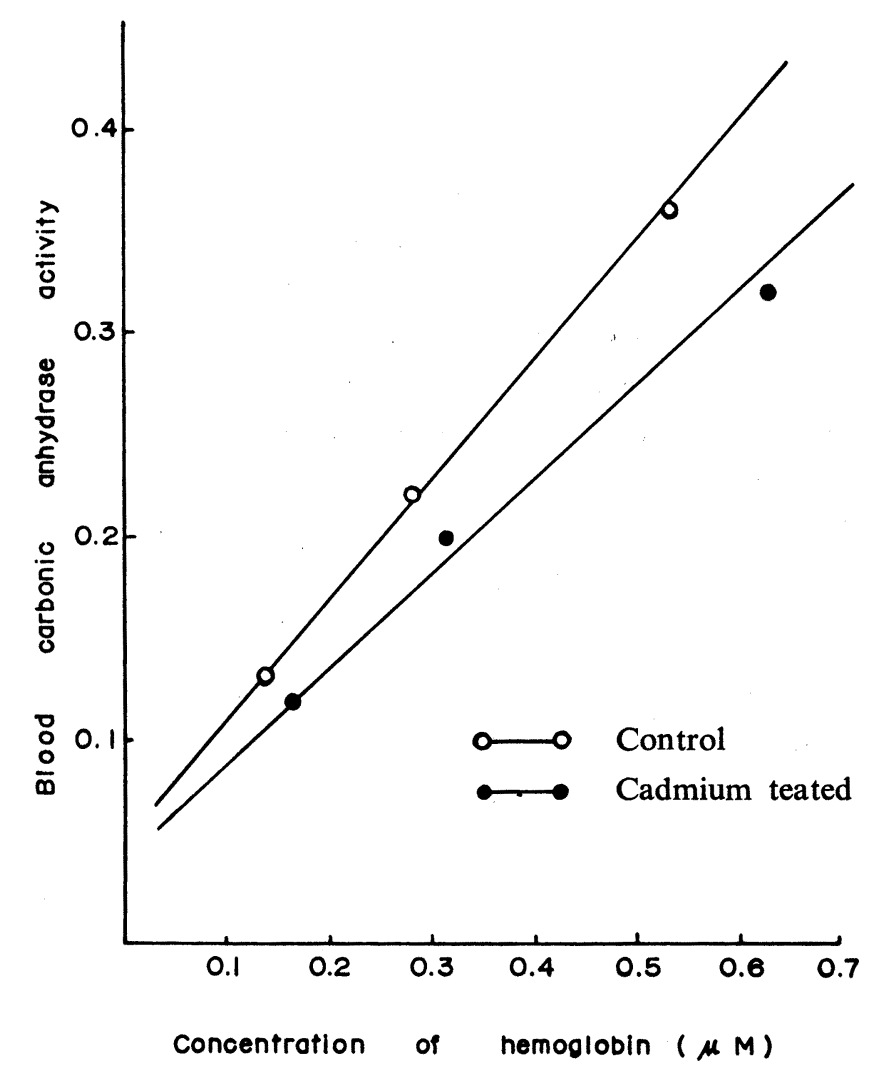

Fig. 4. Relationship between blood carbonic anhydrase activity and hemoglobin concentration in control and cadmium-treated mice. Animals were sacrificed $8 \mathrm{hr}$ after a single s.c. injection of $\mathrm{CdCl}_{2} \cdot 2 \frac{1}{2} \mathrm{H}_{2} \mathrm{O}$ in a dose of $10 \mathrm{mg} / \mathrm{kg}$. Each point represents the mean of six animals. 
TABLE 3. True carbonic anhydrase activity (CAA) in the liver.

\begin{tabular}{lccccc}
\hline Group & $\begin{array}{c}\text { No. of } \\
\text { mice }\end{array}$ & $\begin{array}{c}\text { Total CAA } \\
\text { in sample }\end{array}$ & $\begin{array}{c}\text { Contained blood } \\
\text { Hb }(\mu \mathrm{M})\end{array}$ & $\begin{array}{c}\text { CAA derived } \\
\text { from B }\end{array}$ & $\begin{array}{c}\text { D } \\
\text { A-C }\end{array}$ \\
\hline Control & 6 & $\mathbf{0 . 4 9} \pm 0.04$ & $\mathbf{0 . 0 7} \pm 0.02$ & $\mathbf{0 . 0 9} \pm 0.01$ & $\mathbf{0 . 4 0 \pm 0 . 0 4}$ \\
Cd-treated & 6 & $\mathbf{0 . 3 9} \pm 0.03^{*}$ & $\mathbf{0 . 1 2} \pm 0.04$ & $\mathbf{0 . 1 0 \pm 0 . 0 2}$ & $\mathbf{0 . 2 9} \pm 0.02^{*}$ \\
\hline
\end{tabular}

All values indicate mean \pm S.D. Carbonic anhydrase activity in $A$ and $D$ is expressed per milligram of protein. Enzymic activity in $\mathbf{C}$ was calculated from Fig. 4.

$*: \mathbf{P}<0.05$ when compared with control values.

TABLE 4. True carbonic anhydrase activity (CAA) in the kidney.

\begin{tabular}{lccccc}
\hline Group & $\begin{array}{c}\text { No. of } \\
\text { mice }\end{array}$ & $\begin{array}{c}\text { Total CAA } \\
\text { in sample }\end{array}$ & $\begin{array}{c}\text { Contained blood } \\
\text { Hb }(\mu \mathrm{M})\end{array}$ & $\begin{array}{c}\text { CAA derived } \\
\text { from B }\end{array}$ & $\begin{array}{c}\text { D } \\
\text { A-C }\end{array}$ \\
\hline Control & 6 & $\mathbf{0 . 9 0} \pm 0.06$ & $\mathbf{0 . 1 6} \pm 0.04$ & $\mathbf{0 . 1 5} \pm 0.02$ & $0.75 \pm 0.07$ \\
Cd-treated & 6 & $\mathbf{0 . 7 1} \pm 0.02^{*}$ & $\mathbf{0 . 1 7 \pm 0 . 0 4}$ & $\mathbf{0 . 1 2 \pm 0 . 0 2}$ & $\mathbf{0 . 5 9 \pm 0 . 0 3 ^ { * }}$ \\
\hline
\end{tabular}

All values indicate mean \pm S.D. Carbonic anhydrase activity in $A$ and $D$ is expressed per milligram of protein. Enzymic activity in $\mathbf{C}$ was calculated from Fig. 4.

${ }^{*} \mathbf{P}<0.05$ when compared with control values.

carbonic anhydrase activity in the liver and kidney. Therefore, the same experiment was repeated again and enzymic activity was examined $8 \mathrm{hr}$ after $\mathrm{Cd}$ injection. As shown in Fig. 4, in both control and experimental groups, an approx. linear relation was observed between enzymic activity and blood hemoglobin within final concentration ranges of approx. 0.1-0.6 $\mu \mathrm{M}$ which correspond to diluted blood from 16,000 to 4,000 fold. Tables 3 and 4 show the true enzymic activity of liver and kidney which was corrected for the contaminated blood enzymic activity. It may be concluded from the above results that true enzymic activity in both liver and kidney is also decreased by $\mathrm{Cd}$ administration with contaminated blood having little influence therein.

Absorption and distribution of ${ }^{115 \mathrm{~m}} \mathrm{CdCl}_{2}$

In control group $50 \mu \mathrm{Ci} / 1$ of carrier-free ${ }^{115 \mathrm{~m}} \mathrm{CdCl}_{2}$ solution (contained 0.35 PPM of Cd) and in experimental group $50 \mu \mathrm{Ci} / 1$ of carrier-containing ${ }^{115 \mathrm{~m}} \mathrm{CdCl}_{2}$ solution (contained 146 PPM of Cd) were given as drinking fluid ad lib. respectively. Whole-body radioactivity was measured at one week intervals up to day 31. As shown in Fig. 5 and Table 5 , whole-body retention of ${ }^{115 \mathrm{~m}} \mathrm{Cd}$ was significantly less in the carrier group. The average $\mathrm{Cd}$ uptake for 30 days (as computed from specific radioactivity between radioactivie and non-radioactive $\mathrm{Cd}$ ) was $0.56 \mu \mathrm{g} /$ day in the carrier-free group and $0.1 \mathrm{mg} /$ day in the carrier group. Cd concentrations in liver and kidney at day 31 , as computed from ${ }^{115 \mathrm{~m}} \mathrm{Cd}$ uptake rates according to specific radioactivity, were 0.04 PPM and 0.15 PPM respectively in the carrier-free group and 24 PPM each in the carrier group (Table 5). 


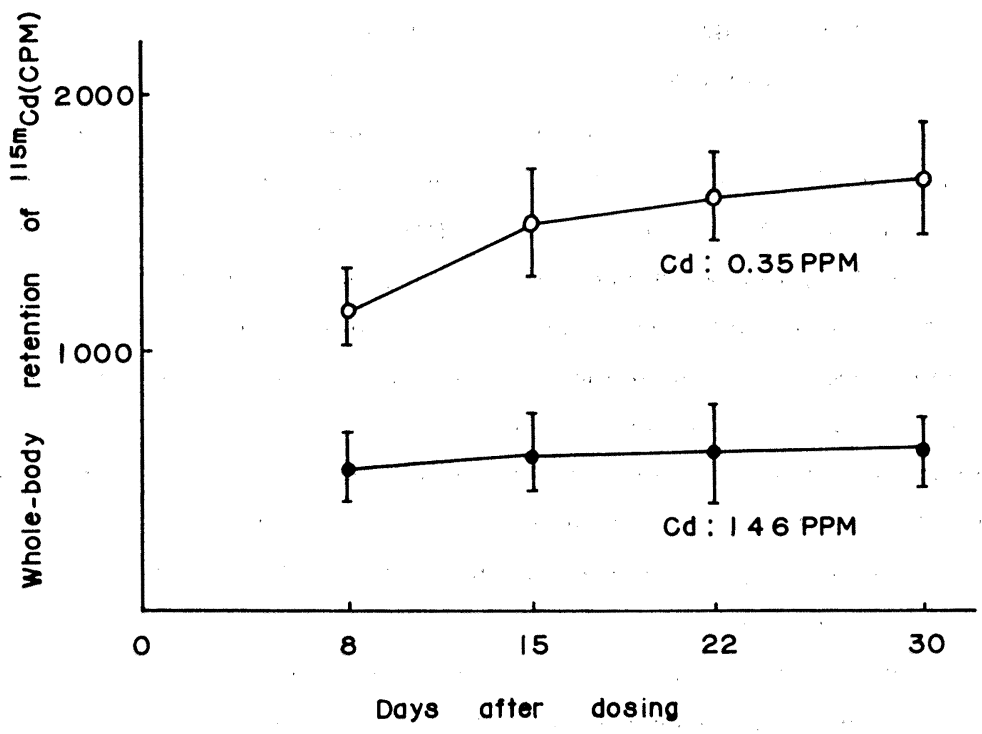

FIG. 5. Effect of carrier on the whole-body retention of ${ }^{115 \mathrm{~m}} \mathrm{Cd}$.

TABle 5. Distribution of $\mathrm{CdCl}_{2}$.

\begin{tabular}{cccc}
\hline \multicolumn{1}{c}{ Group } & $\begin{array}{c}\text { No. of } \\
\text { mice }\end{array}$ & \multicolumn{2}{c}{ Cd concentration $(\mathrm{PPM})^{+}$} \\
\cline { 3 - 4 } & 10 & $0.04 \pm 0.01$ & Kidney \\
\hline $\begin{array}{l}\text { Carrier-free } \\
(\text { Cd 0.35 ppM) }\end{array}$ & 10 & $24 \pm 3$ & $0.15 \pm 0.04$ \\
$\begin{array}{l}\text { Carrier } \\
(\text { Cd 146 PPM) }\end{array}$ & & & $24 \pm 4$ \\
\hline
\end{tabular}

+ : 1-month after oral administration. Each value represents the mean \pm S.D.

\section{DISCUSSION}

As mentioned in the introduction, several investigators have attempted to use the changes of some enzymic activities as diagnostic indices of $\mathrm{Cd}$ poisoning however, more sensitive reactions to $\mathrm{Cd}$ have yet to be found.

Meldrum and Roughton (5) have reported previously that $\mathrm{Cd}\left(\mathrm{CdSO}_{4}\right.$ and $\mathrm{CdCl}_{2}$ ) had no in vitro effect on the carbonic anhydrase activity of $\mathrm{Ca}_{3}\left(\mathrm{PO}_{4}\right)_{2}$ purified enzyme preparation obtained from ox corpuscles, although the enzymic activity was inhibited in vitro by $\mathrm{ZnSO}_{4}, \mathrm{HgCl}_{2}, \mathrm{CuSO}_{4}, \mathrm{AgNO}_{3}, \mathrm{HAuCl}_{4}$ and $\mathrm{Va}$ (sulfate). It is strange however that $\mathrm{Cd}\left(\mathrm{CdSO}_{4}\right.$ and $\left.\mathrm{CdCl}_{2}\right)$ which belong to the same group as $\mathrm{Zn}$ and $\mathrm{Hg}$ in the periodic table do not exert any changes on the blood enzymic activity. On the other hand, Hodgen et al. (6) reported a decrease of carbonic anhydrase activity in rat testis in the early stage after a single s.c. injection of $\mathrm{CdCl}_{2}$ with an increase of its enzymic activity in the later stage. They suggested that the increased enzymic activity may be caused by a haemorrhage in the testis. The experimental results reported by Johnson and Walker (7) with rat and 
domestic fowl testis are similar to the above. We also have observed the inhibitory effect of $\mathrm{Cd}$ on carbonic anhydrase activity of mouse testes in vivo (unpublished).

In the present experiments, the effect of $\mathrm{Cd}$ on both carbonic anhydrase and catalase activities from mouse liver, kidney and blood were examined and it was found that chronic administration of $\mathrm{Cd}$ inhibited enzymic activities. We previously observed however that carbonic anhydrase and catalase activities were inhibited in the liver damaged by carbon tetrachloride or ethionine administration without significant changes of blood enzymic activity in many cases (9). Furthermore, decreases of liver carbonic anhydrase activity were also observed in cancer-bearing mice $(12,13)$ without any significant changes in the enzymic activity of kidney and blood regardless of the presence of hypochromic anemia. These data indicate that the decrease of liver carbonic anhydrase activity is not specific to $\mathrm{Cd}$ poisoning and change of blood enzymic activity does not always agree with that in hemoglobin concentration.

In the present experiments, decrease of blood enzymic activity did not accompany the decrease of hemoglobin concentration in acute Cd poisoning (Figs. 1 and 3). Fox et al. (14) reported that anemia is the most severe effect of $\mathrm{Cd}$, however, we assume that this was seen when a large dose of $\mathrm{Cd}$ was given over a long time and blood carbonic anhydrase activity was more sensitive to $\mathrm{Cd}$ than hemoglobin concentration in an early stage. This reaction appears useful as an index in acute $\mathrm{Cd}$ poisoning however, both blood enzymic activity and hemoglobin concentration were decreased by chronic Cd administration, the changes in the latter being greater than in the former.

The precise mechanism of inhibitory action of $\mathrm{Cd}$ on carbonic anhydrase activity in liver, kidney and blood is not clear at present, however, the following hypothesis can be made. In acute Cd poisoning, decrease of blood enzymic activity may have no direct relation with hypochromic anemia. Gunn et al. (15) have reported that some thiol compounds, e.g., cysteine and BAL prevented vascular damage to mouse testis caused by $\mathrm{Cd}$, though other thiol compounds, e.g., glutathione and methionine had no protective effect. These data seem to indicate a direct action of $\mathrm{Cd}$ on $\mathrm{SH}$ radical in carbonic anhydrase molecules as seen in the case of mercury (16). Furthermore, Cd may inhibit enzyme synthesis, although this subject has so far not been given recognition.

It is well known that carbonic anhydrase is a zinc-metalloenzyme. If $\mathrm{Zn}$ concentrations or enzymes are diminished by $\mathrm{Cd}$ an inhibition of the enzymic activity may be induced as a consequence. Several data are however inconstant with this assumption: Fox et al. (14) have reported that $\mathrm{Cd}$ produced an increased concentration of $\mathrm{Zn}$ in the erythrocytes but a decreased concentration in the tibia, whereas the $\mathrm{Zn}$ concentration in the liver and kidney was not affected. Powell et al. (17) have reported that dietary Cd decreased absorption and tissue distribution of ${ }^{65} \mathrm{Zn}$ in goats. Gunn et al. (18) have reported that $\mathrm{Cd}$ in rats interfers with fecal excretion of ${ }^{65} \mathrm{Zn}$, resulting in an increased retention of radioactive $\mathrm{Zn}$ in liver and kidney. These data indicate a complicated relation between $\mathrm{Zn}$ and $\mathrm{Cd}$. The interactions between $\mathrm{Zn}, \mathrm{Fe}, \mathrm{Cu}$ and $\mathrm{Cd}$ may also play an important part in this phenomena $(19,20)$. Antagonism between $\mathrm{Zn}$ and $\mathrm{Cd}$ affecting carbonic 
anhydrase activity is not yet clear, however in view of the above observations, it appears necessary to consider in conjugation with $\mathrm{Cd}$ concentration in blood, excreta and organs as well as other laboratory data in the diagnosis of chronic $\mathrm{Cd}$ poisoning.

Tracer experiments with ${ }^{115 \mathrm{~m}} \mathrm{Cd}$ disclosed the fate of $\mathrm{Cd}$ which could not be determined by other analytical methods. When $\mathrm{Cd}$ concentrations in liver and kidneys are taken against the changes in enzymic activity, a considerable low concentration of Cd can affect the enzymic activity. These observations indicate the significance of the enzyme in $\mathrm{Cd}$ poisoning.

Liver and kidney tissues obtained from Cd-water drinking animals for 90 days were examined morphologically. No alterations were seen. After a single s.c. injection of $\mathrm{Cd}$, only hyperemia in the testes was observed macroscopically with no pathological findings in liver and kidneys.

Acknowledgements: This work was supported by a grant from Japanese Education Ministry in aid for fundamental scientific research in 1971. We wish to thank Dr. M. Honma, First Department of Pathology, Gunma University, for his support in pathological examinations.

\section{REFERENCES}

1) Friberg, L.: Acta med. scand. (Suppl. 240) 138, 1 (1950)

2) Piscator, M.: Arch. Environ. Health 12, 345 (1966)

3) Stowe, H.D. And Gover, R.A.: Fed. Proc. 30, 238Abs. (1971)

4) JaCoBS, E.E., JACOB, M., SANAdi, D.R. AND BRADley, L.B.: J. biol. Chem. 223,147 (1956)

5) Meldrum, N.U. and Roughton, F.J.W.: J. Physiol. 80, 113 (1933)

6) Hodgen, G.D., Butler, W.R. And Gomes, W.R.: J. Reprod. Fert. 18, 156 (1969)

7) Johnson, A.D. and Walker, G.P.: J. Reprod. Fert. 23, 463 (1970)

8) Altschule, M.D. AND Levis, H.D.: J. biol. Chem. 180, 557 (1949)

9) Suzuki, S., Ogawa, E., Shibata, K. and Tsuzuki, H.: Japan. J. Pharmacol. 17, 393 (1967)

10) LaYnf, E. Methods in Enzymology, Edited by Colowick, S.P. AND KaPlan, N., 3, p. 450, Academic Press, New York (1957)

11) Kuroda, K., Yoshikawa, H., Nakao, K. and Wakisaka, K.: Blood Chemistry, p. 96, Asakura Press, Tokyo (1963) (In Japanese)

12) Suzuki, S., Ogawa, E. And Shibata, K.: Gunma J. Med. Sci. 10, 121 (1961)

13) Suzuki, S. ANd Ogawa, E.: Gunma J. Med. Sci. 16, 74 (1967)

14) Fox, M.R.S., Fry, B.E.Jr., Harland, B.F., Schertel, M.E. and Weeks, C.E.: J. Nutr. 101, 1295 (1971)

15) Gunn, S.A., Gould, T.C. And Anderson, W.A.D.: Proc. Soc. exp. Biol. Med. 122, 1036 (1966)

16) Fridborg, K., Kannan, K.K., Liljas, A., Lundin, J., Strandberg, B., Strandberg, R., Tilander, B. ANd Wiren, G.: J. Mol. Biol. 25, 505 (1967)

17) Powell, G.W., Miller, W.J. and Blackmon, D.M.: J. Nutr. 93, 203 (1967)

18) Gunn, S.A., Gould, T.C. And Anderson, W.A.D.: Proc. Soc. exp. Biol. Med. 111, 559 (1962)

19) Hill, C.H., Matrone, G., Payne, W.L. and Barber, C.W.: J. Nutr. 80, 227 (1963)

20) Bunn, C.R. And Matrone, G.: J. Nutr. 90, 395 (1966) 